Research Article

\title{
A study to evaluate antioxidant and hepatoprotective activity of aqueous extract of roots of Valeriana wallichii in $\mathrm{CCl}_{4}$ induced hepatotoxicity in rats
}

\author{
Shariq Naeem Syed ${ }^{1}$, Waseem Rizvi²*, Anil Kumar ${ }^{2}$, Aijaz Ahmad Khan ${ }^{3}$, Shagufta Moin ${ }^{4}$, \\ Akif Ahsan ${ }^{4}$
}

\author{
${ }^{1}$ Department of Pharmacology, \\ MAMC, New Delhi - 110002 , \\ India, \\ ${ }^{2}$ Department of \\ Pharmacology, JNMC, AMU, \\ Aligarh - 202 002, \\ Uttar Pradesh, India, \\ ${ }^{3}$ Department of \\ Anatomy, JNMC, AMU, \\ Aligarh - 202 002, \\ Uttar Pradesh, India, \\ ${ }^{4}$ Department of \\ Biochemistry, JNMC, AMU, \\ Aligarh - 202 002, \\ Uttar Pradesh, India
}

Received: 26 January 2014 Accepted: 02 February 2014

*Correspondence to: Dr. Waseem Rizvi, Email: waseemnakhat@gmail. com

(C) 2014 Syed SN et al. This is an open-access article distributed under the terms of the Creative Commons Attribution Non-Commercial License, which permits unrestricted noncommercial use, distribution, and reproduction in any medium, provided the original work is properly cited.

\begin{abstract}
Background: Drugs for liver ailments have been important in research, but still the number of drugs acting on various hepatic diseases is very limited. This study, for the first time, evaluates the hepatoprotective activity of aqueous extract of the roots of Valeriana Wallichii in albino rats.

Methods: The hepatotoxicity was induced by $\mathrm{CCl}_{4}$. Animals were divided into 5 groups of 6 animals each. Group I (Normal control) was given only distilled water. Group II (Negative control)was administered $\mathrm{CCl}_{4}$ for 7 days while Group III (Positive control) was given silymarin and $\mathrm{CCl}_{4}$ for 7 days. The test groups (Group IV \& V) were given an aqueous extract of roots of $V$. Wallichii in a dose of $300 \mathrm{mg}$ and $500 \mathrm{mg} / \mathrm{kg}$, respectively. The animals were sacrificed on 8 days and blood was collected for biochemical analysis (aspartate aminotransferase [AST], alanine transaminase (ALT) and alkaline phosphatase). Liver tissue was extracted for histopathological examination and in vivo antioxidant tests Catalase [CAT], glutathione and malondialdehyde. The extract was also subjected to in vitro antioxidant tests (Total reducing power and total phenolic content).

Results: The test extracts in the dose of $500 \mathrm{mg} / \mathrm{kg}$ were shown a significant decrease in the levels of AST and ALT ( $>00.05$ ) and CAT activity. $300 \mathrm{mg} / \mathrm{kg}$ dose of extract showed minimal hepatoprotection. The findings were confirmatory to histopathology. Conclusion: The aqueous extract of roots of $V$. Wallichii in a dose of $500 \mathrm{mg} / \mathrm{kg}$ offers partial protection against hepatotoxicity produced by $\mathrm{CCl}_{4}$ in albino rats.
\end{abstract}

Keywords: Valeriana wallichii, Aqueous extract, Roots, Hepatoprotective, Antioxidant

\section{INTRODUCTION}

As the primary organ for detoxification of endogenous as well as exogenous compounds, the liver is also a major site for their assaults. Drugs have been devised to either decrease the intensity of the injury such or increase healing, like principles derived from plants. Plants, due to the presence of various phytochemicals, have antioxidant property which in turn prevents injury caused by free radicals. In this study, the plant Valeriana wallichii was selected on the basis of their folklore claim in the book by Hakim Abdul Wahid $(1961)^{1}$ and experimented for potential hepatoprotection in albino rats. It is known as "Tagar" in Hindi and Indian Valerian in English.

\section{METHODS}

The roots of Valariana wellichi was purchased from local herbal dealer. It was identified \& authenticated by botanist and a voucher specimen was submitted 
(1631.s.HWD). The roots was powdered and extracted in ethanol for 72 hrs in Soxhlet's apparatus. The yield of Valariana wellichii aqueous extract (VWAE) was found to be $9.88 \%$.

The study was approved by Institutional Animal Ethics Committee, JNMC,AMU,Aligarh(401/CPCSEA-23/3/2012). The animals used were albino rat of Charles Foster strain of either sex weighing 200-250 g. All animal experiments were carried out as per the guidelines of IAEC \& CPCSEA.

Phytochemical analysis was done by the methods described by Harborne. ${ }^{2}$ Reducing sugars, saponins, tannins, and Alkaloids were found to be present in the VWAE.

The acute toxicity testing was done according to the OECD guidelines - 423 for testing of chemicals. As a dose of $2 \mathrm{~g} / \mathrm{kg}$ b.w. of VWAE was found to be non-toxic to the experimental animals. Hence, lower doses of $300 \mathrm{mg} / \mathrm{kg}$ b.w and $500 \mathrm{mg} /$ $\mathrm{kg}$ b.w were chosen for experimentation. The hepatic damage was induced by giving carbon tetrachloride $\left(\mathrm{CCl}_{4}\right)$ giving orally for 7 days. ${ }^{3}$

The animals were divided into 5 groups of 6 animals each. All the drugs were given orally every day for 7 days along with $\mathrm{CCl}_{4}$ treatment.

Group I: Normal control - Distilled water $1 \mathrm{ml} / \mathrm{kg}$

Group II: Negative control $-\mathrm{CCl}_{4}(1 \mathrm{ml} / \mathrm{kg}$ mixed in olive oil in the ratio of $1: 1[\mathrm{v} / \mathrm{v}])$

Group III: Positive control - Silymarin (50 mg/kg/day) + $\mathrm{CCl}_{4}(1 \mathrm{ml} / \mathrm{kg})$

Group IV: Test group - VWAE $300 \mathrm{mg} / \mathrm{kg}$ b.w

Group V: Test group - VWAE $500 \mathrm{mg} / \mathrm{kg}$ b.w.

The animals were sacrificed on 8 days. The serum collected from blood was used for biochemical analysis of liver function (aspartate aminotransferase [AST], alanine transaminase [ALT] and alkaline phosphatase [ALP])., The liver tissue was dissected out for histopathological examination and homogenate of liver (in $10 \% \mathrm{w} / \mathrm{v}$ of phosphate buffer [0.2 M, pH-6.6]) tissue was used to perform antioxidant tests viz. catalase (CAT), ${ }^{6}$ reduced glutathione $(\mathrm{GSH})^{7}$ and malondialdehyde (MDA). ${ }^{8}$

The extract was also analyzed for free radical scavenging activity using serially diluted solution of VWAE between $0.25 \mathrm{mg} / \mathrm{ml}$ to $2.0 \mathrm{mg} / \mathrm{ml}$. Total reducing power was performed according to the method described by Oyaizu 9 and total phenolic content was quantified as Gallic acid equivalents (GAE) \& done as described by Saucier. ${ }^{10}$

The percentage of hepatic protection offered by the drug was calculated by using the following formula: ${ }^{11}$

$\mathrm{H}=1-((\mathrm{T}-\mathrm{v}) / \mathrm{C}-\mathrm{V})) \times 100$

Where $\mathrm{H}=$ Percentage of hepatoprotection, $\mathrm{T}=$ Mean value of group treated with test drug $+\mathrm{CCl}_{4}, \mathrm{C}=$ Mean value of group treated with $\mathrm{CCl}_{4}$ and $\mathrm{V}=\mathrm{Mean}$ value for the control group animals.

The results were presented as mean \pm standard error of the mean. The groups were compared by one-way analysis of variance followed by posthoc "Dunnett's multiple comparison test" to analyze statistical significance. $\mathrm{p}<0.05$ was considered to be significant.

\section{RESULTS}

The in vitro radical scavenging tests showed a dose dependent increase in the total reducing power of the VWAE (Figure 1) and found to have total phenolic content of $29.9 \mathrm{mg} \mathrm{GAE} / \mathrm{g}$ extract (optical density of 0.075 at $760 \mathrm{~nm}$ ).

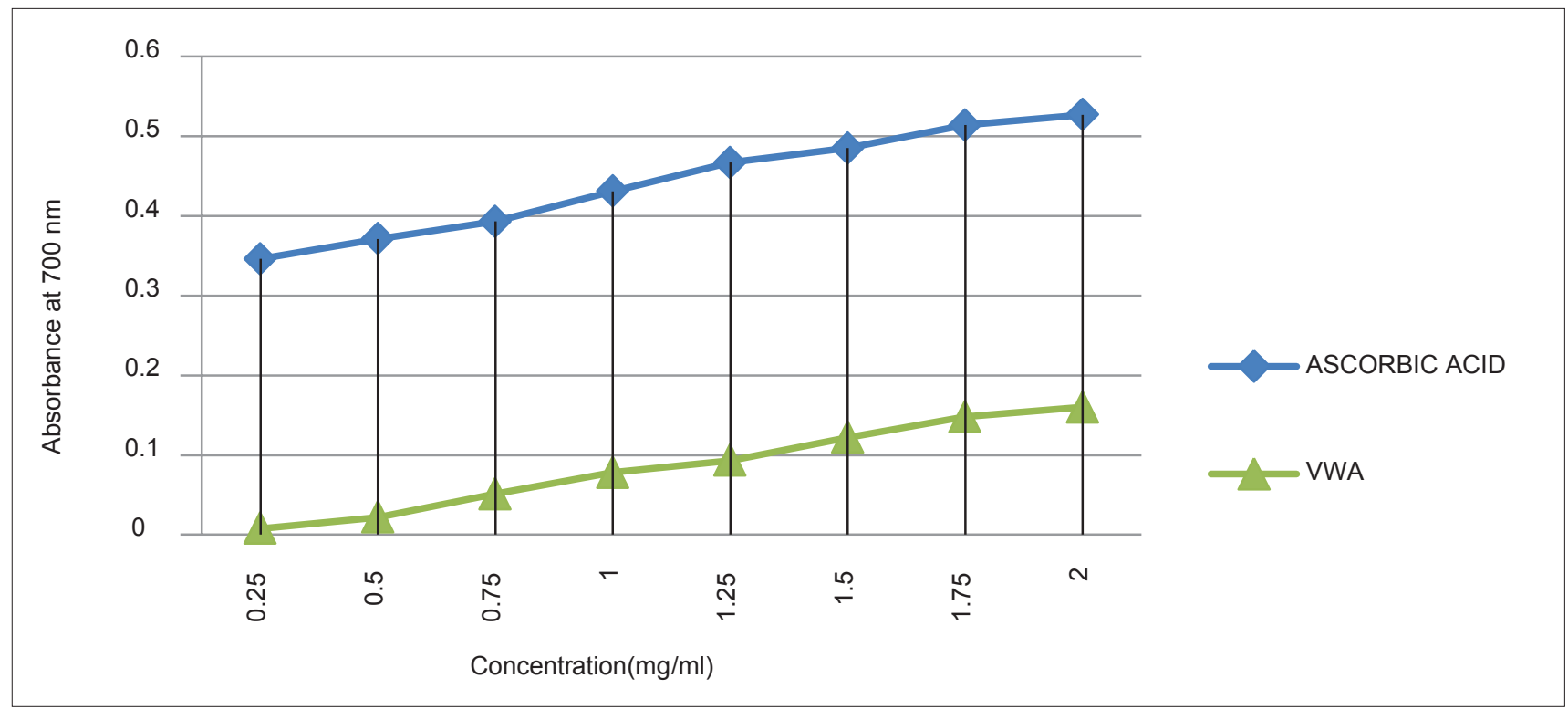

Figure 1: Total reducing power of aqueous extract of Valariana wallichii. 
The hepatoprotective activity was measured against the liver toxicity induced by $\mathrm{CCl}_{4}$ as shown in Table 1. CYP2E1 and CYP2B1/B2 metabolizes $\mathrm{CCl}_{4}$ to $\mathrm{CCl}_{3}$ * free radicals. ${ }^{12,13}$ These radicals damage the integrity of liver cells and cause the release of enzymes like transaminases (AST and ALT) and ALP as shown in the negative control. The positive control limited the increase of serum enzymes to a level of $60.5 \pm 6.4 \mathrm{IU} / \mathrm{ml}$ for ALT and $55 \pm 2.6 \mathrm{IU} / \mathrm{ml}$ for AST and ALT, respectively. The percentage hepatoprotection as a function of ALT was found to be $21.1 \%$ for VWAE 500 while VWAE 300 showed minimal activity (Table 1).

The antioxidants scavenge the free radicals in the cells and decreases the damage caused by them. In the experiment, the antioxidant activity was measured as the amount of CAT consumed per minute and total GSH present in liver tissue. As expected there was a significant decrease in the levels and activity of GSH and CAT in the presence of $\mathrm{CCl}_{4}$ alone. VWAE 500 showed an increase in the levels of CAT $(p<0.05)$ thereby suggesting the probable mechanism of action. There was an increase in the levels of GSH and decrease in MDA levels in both VWAE 500 and VWAE 300 extracts as compared to negative control, but the rise is not statistically significant. Overall, the VWAE $500 \mathrm{mg}$ group fared better than VWAE $300 \mathrm{mg}$ implying dose dependent increase in hepatoprotective and antioxidant activity (Figure 2).

Figure 2 shows the histopathological features of the different control groups. There was a complete loss of hepatic architecture and presence of inflammatory infiltrates in the negative control group. VVAE $300 \mathrm{mg}$ showed inflammatory infiltrates, the architecture was disrupted in most part of the field (Figure 3) while VVEE $500 \mathrm{mg}$ demonstrated superior results than $300 \mathrm{mg}$, apart from a few local areas of necrosis and coagulative changes rest of the architecture was well maintained (Figure 3).

\section{DISCUSSION}

The aqueous extracts of roots of $V$. Wallichii showed dose dependent hepatoprotective activity in $\mathrm{CCl}_{4}$ treated rats. The hepatoprotective activity of the extracts can be due to its antioxidant activity as demonstrated in the study. The free radicals scavenging activity of the extract might

Table 1: Hepatoprotective activity and in vivo antioxidant activity of aqueous extract of Valeriana Wallichii

\begin{tabular}{|c|c|c|c|c|c|}
\hline \multirow{2}{*}{$\begin{array}{l}\text { Biochemical test } \\
(\text { mean } \pm \text { SEM) }\end{array}$} & \multicolumn{5}{|c|}{ Groups (percentage hepatoprotection) } \\
\hline & $\begin{array}{l}\text { Normal } \\
\text { contorl } \\
\text { (Water) }\end{array}$ & $\begin{array}{l}\text { Negative } \\
\text { control } \\
\left(\mathrm{CCl}_{4}\right)\end{array}$ & $\begin{array}{l}\text { Positive control } \\
\text { (Silymarin) }\end{array}$ & $\begin{array}{l}\text { Valeriana } \\
\text { Wallichii aqueous } \\
\text { (300 mg/kg) } \\
\text { (VWAE 300) }\end{array}$ & $\begin{array}{l}\text { Valeriana Wallichii } \\
\text { aqueous } \\
\text { (500 mg/kg) } \\
\text { (VWAE 500) }\end{array}$ \\
\hline $\operatorname{AST}(\mathrm{IU} / \mathrm{ml})$ & $39.1 \pm 1.4$ & $154.0 \pm 6.1 * * *$ & $60.5 \pm 6.4 * * *(81.3 \%)$ & $150.3 \pm 5.7(3.1 \%)$ & $129.6 \pm 3.1 *(21.1 \%)$ \\
\hline $\operatorname{ALT}(\mathrm{IU} / \mathrm{ml})$ & $38.8 \pm 1.2$ & $161.3 \pm 2.2 * * *$ & $55 \pm 2.6 * * *(86.7 \%)$ & $155.7 \pm 5.0(4.3 \%)$ & $146.7 \pm 3.96 *(11.7 \%)$ \\
\hline $\operatorname{ALP}(\mathrm{KAU} / \mathrm{dl})$ & $42.8 \pm 2.3$ & $78.6 \pm 4.2 * * *$ & $50.2 \pm 4.7 * *(79.4 \%)$ & $69.3 \pm 4.4(25.9 \%)$ & $62.3 \pm 6.9(45.4 \%)$ \\
\hline Catalase (U/min/mg) & $82.2 \pm 3.7$ & $47.4 \pm 1.6^{* * *}$ & $67.7 \pm 1.0 * * *$ & $48.4 \pm 1.1$ & $50.0 \pm 1.8^{*}$ \\
\hline $\mathrm{GSH}(\mu \mathrm{mol} / \mathrm{mg})$ & $5.25 \pm 0.21$ & $2.15 \pm 0.25 * * *$ & $4.44 \pm 0.11 * * *$ & $2.39 \pm 0.06$ & $2.67 \pm 0.15$ \\
\hline MDA (nmol/mg) & $203.9 \pm 8.9$ & $445.9 \pm 17.8^{* * *}$ & $255.8 \pm 7.7 * * *$ & $417.1 \pm 18.8$ & $399.9 \pm 19.3$ \\
\hline
\end{tabular}
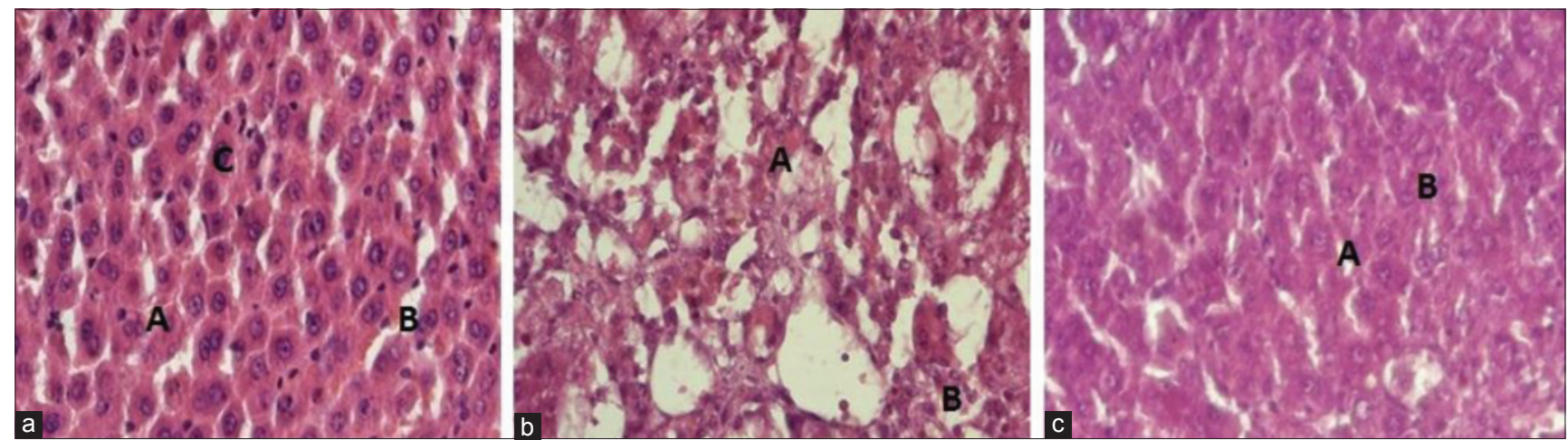

Figure 2: Histology of control groups: (a) Photomicrograph of rat liver from normal control group showing normal liver microstructure with intact hepatic cords (A) and sinusoids (B). Hepatocytes (C) show normal contour. There is neither obvious congestion nor inflammatory cell infiltration. (H \& E stain, $\times 400)$. (b) Photomicrograph of rat liver from negative control group shows almost complete disorganization of hepatic microstructure. Most of the hepatocytes show either lytic or coagulative changes (A) and there is inflammatory cell infiltration. (c) Photomicrograph of rat liver from positive control group showing maintained hepatic microstructure. The hepatic cords (A) are intact and the contour of hepatocytes appear very akin to normal (B). There is no obvious inflammatory cell infiltration. 

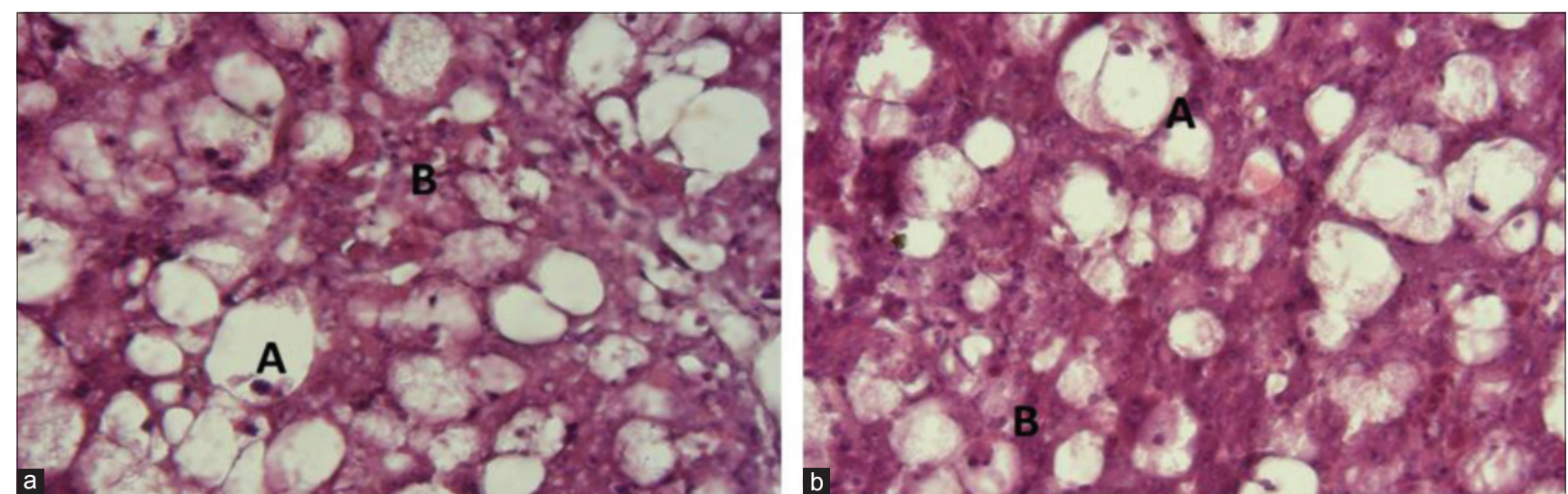

Figure 3: Histology of test groups. (a) Photomicrograph of rat liver from test group VWA 300 mg/kg showing almost marked degeneative changes in the liver with distortion of hepatic microstructure, ballooning of hepatocytes (A) and inflammatory cell infiltration (B) (H \& E stain, $\times 400)$. H \& E stain. (b) Photomicrograph of rat liver from test group VWA $500 \mathrm{mg} / \mathrm{kg}$ showing evidence of degenerative changes in the liver as shown by ballooning of hepatocytes (A) and sinusoids (B). However, the presence of inflammatory cells is not too obvious, (H \& $\mathbf{E}$ stain, $\times 400)$.

have protected the hepatocytes form the reactive species like $\mathrm{CCl}_{3}{ }^{*}$. In our study, the ethanolic extract of roots of $V$. Wallichii found to possess phytochemicals such as alkaloids, tannins, saponins, and reducing sugars which was confirmatory to the findings of Subhan et al. ${ }^{14}$ Kalim et al. (2010) also demonstrated high concentration of flavonoids, phenols and ascorbic acid content in root extract of $V$. Wallichii. They also demonstrated free radical scavenging activity of the extract and correlated it to the cytoprotective activity in U937 cell lines. ${ }^{15}$ Among many phytochemicals, Hesperidin extracted from valerian species have shown to have antioxidant properties which may be one of the reasons for its antioxidant properties. ${ }^{16,17}$

\section{CONCLUSION}

Hence, we conclude that the aqueous extracts of $V$. Wallichii in a dose of $500 \mathrm{mg}$ offer dose dependent partial protection against hepatotoxicity induced by $\mathrm{CCl}_{4}$.

\section{ACKNOWLEDGMENTS}

We thank JNMC, AMU for financial support provided for the study. We also thank Dr. Onkar Singh and Mr. Shabbir Khan for technical assistance.

Funding: JNMC, AMU for financial support provided for the study

Conflict of interest: None declared

Ethical approval: The ethical clearance was taken from Institutional Animal ethical Committee, JNMC, AMU, India (401/CPCSEA-23/3/2012)

\section{REFERENCES}

1. Wahid HA, Siddiqui HH. A Survey of Drugs. $2^{\text {nd }}$ ed. Delhi: IHMMR; 1961: 78.
2. Harborne JB. Phytochemical Methods. London: Chapman and Hall; 1996: 52-105.

3. Anandan R, Jayakar B, Karar B, Babuji S, Manavalan R, Kumar RS. Effect of ethanol extract of flowers of Vitex trifolia linn. On CCl4 induced hepatic injury in rats. Pak J Pharm Sci. 2009;22(4):391-4.

4. Reitman S, Frankel S. A colorimetric methods for the determination of serum levels of glutamic oxaloacetic acid and pyruvic acid transaminases. Am J Clin Pathol. 1957; 10:394-9.

5. Marsh WH, Fingerhut B, Kirsch E. Adaption of alkaline phosphatise method for automatic colorimetric analysis. Clin Chem. 1959;5:119-26.

6. Beers RF, Sizer IW. A spectrophotometric method for measuring the breakdown of hydrogen peroxide by catalase. J Biol Chem. 1952;195(1):133-40.

7. Ellman GC. Tissue sulfhydryl groups. Arch Biochem Biophys. 1959;82(1):70-7.

8. Niehans WG, Samuelsson D. Formation of malondialdehyde from phospholipids arrachidonate during microsomal lipid peroxidation. Eur J Biochem. 1968;6(1):126-30.

9. Oyaizu M. Studies on product of browning reaction prepared from glucose amine. Jpn J Nutr. 1986;44:307-15.

10. Saucier CT, Waterhouse AL. Synergetic activity o catechin and other antioxidant. J Agric Food Chem. 1999;47:4491-4.

11. Dsagupta B, Kalita JC, Chowdury A. Hepatoprotective activity of Nelsoniacanescens (lam.) Spreng on acute hepatotoxicity induced by paracetamol. Int J Pharm Pharm Sci. 2012;4(1):107-12.

12. Raucy JL, Kraner JC, Lasker JM. Bioactivation of halogenated hydrocarbons by cytochrome P4502E1. Crit Rev Toxicol. 1993;23:1-20.

13. Gruebele A, Zawaski K, Kapalan D, Novak RF. Cytochrome P4502E1- and cytochrome P4502B1/2B2-catalysed carbon tetrachloride metabolism. Drug Metab Dispos. 1996;24:15-22.

14. Subhan F, Karim N, Ibrar M. Anti-inflammatory activity of methanolic and aqueous extracts of valeriana wallichii $\mathrm{dc}$ rhizome. Pak J Pl Sci. 2007;13(2):103-8.

15. Kalim MD, Bhattacharyya D, Banerjee A, Chattopadhyay S. Oxidative DNA damage preventive activity andantioxidant potential of plants used in Unani system of medicine. BMC Complement Altern Med. 2010;10:77. 
16. Marder M, Viola H, Wasowski C, Fernández S, Medina JH, Paladini AC. 6-methylapigenin and hesperidin: new valeriana flavonoids with activity on the CNS. Pharmacol Biochem Behav. 2003;75(3):537-45.

17. Wilmsen PK, Spada DS, Salvador M. Antioxidant activity of the flavonoid hesperidin in chemical and biological systems. J Agric Food Chem. 2005;15:53(12):4757-61. doi: $10.5455 / 2319-2003 . i j b c p 20140418$

Cite this article as: Syed SN, Rizvi W, Kumar A, Khan AA, Moin S, Ahsan A. A study to evaluate antioxidant and hepatoprotective activity of aqueous extract of roots of Valeriana wallichii in $\mathrm{CCl} 4$ induced hepatotoxicity in rats. Int J Basic Clin Pharmacol 2014;3:2:354-8. 